\title{
Pengembangan Asisten TV Berbasis Internet of Things (IoT) untuk Efisiensi Penggunaan Energi Listrik
}

\author{
Herpendi $^{1}$, Agustin Noor ${ }^{2}$, Rabini Sayyidati ${ }^{3}$ \\ Program Studi Teknik Informatika \\ Politeknik Negeri Tanah Laut \\ Kalimantan Selatan, Indonesia \\ e-mail: ${ }^{1}$ herpendi@politala.ac.id, ${ }^{2}$ agustian@politala.ac.id, ${ }^{3}$ rsayyidati@politala.ac.id \\ Diajukan: 9 Agustus 2019; Direvisi: 29 Agustus 2019; Diterima: 12 Oktober 2019
}

\begin{abstract}
Abstrak
Pemborosan pemakaian listrik terjadi di antaranya pada kebiasaan masyarakat yang membiarkan televisi dalam keadaan mode standby dan meninggalkan televisi dalam keadaan menyala saat tidak ditonton. Televisi yang menyala mengonsumsi listrik hingga 110 watt/jam dan mode standby sebesar 10.96 watt/jam. Kebiasaan ini jika tidak ditanggulangi maka akan memberikan dampak dalam hal persediaan listrik. Penelitian ini bertujuan mengembangkan sebuah sistem yang dapat mengendalikan tombol power on/off dan stop kontak televisi lewat Smartphone Android dan internet. Sistem dibangun menggunakan metode Waterfall dengan tahapan Analisis, Desain, Pengodean, dan Pengujian. Pengendalian dapat dilakukan dengan menekan tombol, perintah suara dan pengaturan waktu pada Smartphone Android. Pengendalian juga dapat dilakukan dengan media internet dengan mengakses URL dan pemilihan button on/off pada website. Pengujian menunjukkan respons waktu pengendalian kurang dari 1 detik dengan jarak di bawah 11 meter menggunakan Smartphone Android dan 1-3 detik dengan media internet. Konsumsi listrik dari hardware yang dibangun sebesar 30 watt/jam. Pemilik televisi dapat menghemat listrik lewat sistem yang dibangun khususnya yang terbiasa tertidur di depan televisi dan lupa mematikan televisi ketika meninggalkan rumah hingga 60 watt/hari.
\end{abstract}

Kata kunci: Android, Mikrokontroler, Listrik, Standby, Televisi.

\begin{abstract}
Waste uses electricity when it is released in the habit of people who use television in standby mode and leave the television on when not being watched. The lit television consumes up to 110 watts/hour of standby mode at 10.96 watts/hour. This habit, if not addressed, will have an impact in terms of electricity supply. This study aims to develop a system that can control power on / off and television's switch via Android and the internet. The system was built using the Waterfall method with the stages of Analysis, Design, Coding and Testing. Control can be done by pressing buttons, voice commands and time settings on an Android Smartphone. Control can also be done with internet media by using URL mechanisms and selecting on / off buttons on website. Tests show the response time is less than 1 second control with a distance of under 11 meters using Smartphone Android and 1-3 seconds with internet media. Electricity consumption from built hardware is 30 watt / hour. Television owners can save electricity through a system built especially those accustomed to falling asleep in front of the television and forget to turn off the television when leaving the house up to 60 watts / day.
\end{abstract}

Keywords: Android, Microcontroller, Electricity, Standby, Television.

\section{Pendahuluan}

Fakta menyatakan bahwa energi listrik ialah kebutuhan dasar dalam aktivitas manusia modern. Listrik sudah tidak dapat lagi dipisahkan dari aktivitas disebabkan begitu terintegrasinya dalam kehidupan sehari-hari yang meliputi pekerjaan, belajar maupun sekedar dalam mendapatkan hiburan. Hingga saat ini kebutuhan akan energi di Indonesia tergolong cukup besar yaitu mencapai kisaran angka 221.296 GWh, dan diprediksi akan selalu meningkat tiap tahunnya [1]. Di beberapa bagian Indonesia kini perlahan telah mengalami krisis energi listrik salah satunya Provinsi Lampung. Krisis terjadi akibat defisit daya listrik yang mencapai angka $200 \mathrm{MW}$, pemadaman bergilir pun tidak terelakkan untuk menstabilkan cadangan yang ada [2]. Tidak dipungkiri Indonesia masih bergantung terhadap batu bara dalam sektor pembangkit 
energi listrik. Pengelolaan sumber daya alam yang tak terbarukan ini haruslah bijaksana, mengingat cadangan batu bara siap tambang hanya mampu bertahan hingga kurang lebih 30 tahun saja [3]. Sumber daya alam terbarukan sudah waktunya menjadi prioritas dalam kebijakan pemerintah, sebab sumber daya ini memiliki peran yang jangka panjang untuk generasi penerus [4].

Lewat program nasionalnya, pemerintah telah melakukan berbagai terobosan dan gerakan untuk menghemat energi listrik di Indonesia. Tahun 2016 misalnya, pemerintah mencanangkan gerakan konservasi energi dengan jargon "Potong 10 persen", tujuannya tidak lain ialah untuk menggandeng masyarakat bersama-sama berhemat dalam pemanfaatan energi listrik. Banyak pola perilaku dalam keseharian masyarakat yang ternyata tanpa disadari membuat biaya tagihan listrik meningkat. Selain biaya tagihan yang membengkak juga memboroskan energi listrik. Padahal diketahui bersama bahwa sumber energi seperti minyak bumi, batu bara, dan gas bumi ketersediaannya terbatas.

Mode standby dapat didefinisikan di mana peralatan elektronik tidak dalam keadaan mati total dan tetap mengonsumsi listrik (terbuang). Namun perangkat listrik tidak seperti bekerja pada fungsi atau keadaan utamanya yaitu power on/switch on. Energi listrik yang hilang terbuang lewat mode ini umumnya disebut dengan "standby loss" dan "leaking electricity" [5]. Mode standby ialah definisi dari penggunaan listrik oleh peralatan elektronik yang tidak dimatikan (power off) atau tidak melakukan fungsi utamanya [6]. Meskipun estimasi penggunaan listriknya relatif kecil berkisar 0,5-10 Watt, walaupun penggunaan dalam jumlah yang besar tetap memicu munculnya masalah yang signifikan yang menjadi isu untuk bangsa. Pakar industri memperkirakan bahwa negara-negara OECD (Organization for Economic Co-operation and Development), $4 \%$ hingga $10 \%$ dari konsumsi listrik perumahan mereka berhubungan erat dengan mode standby [6]. Pada tahun 2008 konsumsi listrik pada TV penduduk Oman mencapai 78.10 Watt per jam saat aktif dan 10.96 Watt per jam saat standby [7]. Listrik yang dikonsumsi oleh peralatan elektronik saat standby bervariasi, tergantung jenis dan teknologi yang diterapkan. Meskipun begitu, pada prinsipnya mode standby tetaplah mengonsumsi energi listrik seperti digambarkan pada diagram blok berikut:

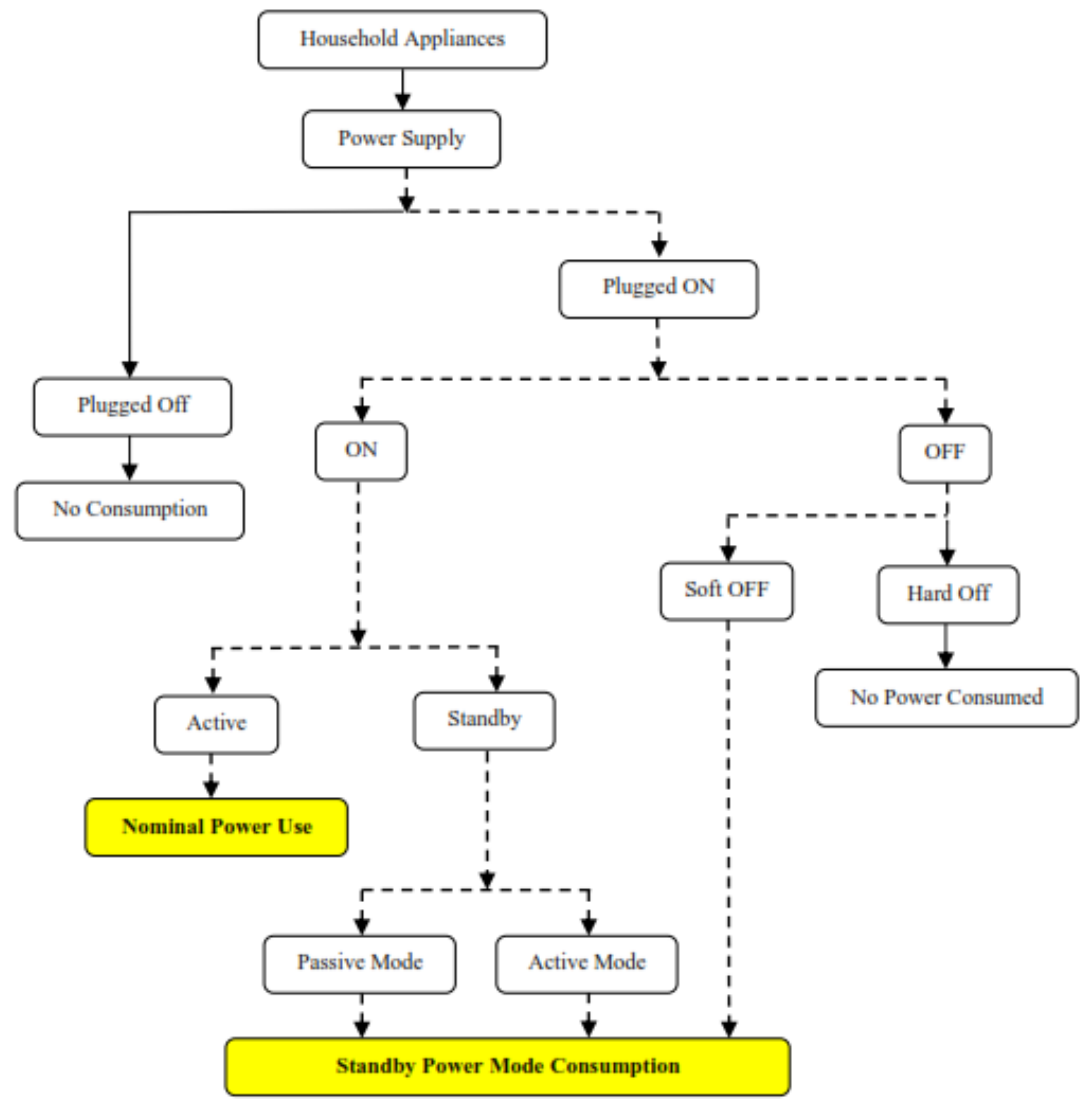

Gambar 1. Diagram blok konsumsi listrik mode standby [8].

Penelitian ini bertujuan membangun sebuah sistem yang dapat melakukan pengendalian tombol Power On/Off dan terminal/stop kontak TV. Sistem dikembangkan dengan tanpa mengurangi fungsi TV, yaitu sistem dibangun terpisah dan standalone (berdiri sendiri). Sistem dibangun dengan Mikrokontroler 
Arduino yaitu papan rangkaian elektronik yang bersifat open source atau satu paket elektronik yang di dalamnya memiliki komponen dasar, berupa sebuah microchip mikrokontroler berjenis AVR yang diproduksi oleh perusahaan Atmel. Mikrokontroler sendiri ialah IC (Integrated Circuit) atau chip yang dapat dilakukan pemrograman lewat komputer [9]. Sistem yang dikembangkan diletakkan atau ditempelkan di sekitar tombol power on/off TV. Sistem yang dikembangkan mampu mematikan (power off) TV di mana TV ditinggalkan dalam keadaan hidup (power on) atau saat pemilik rumah tertidur ketika di depan TV atau meninggalkan rumah dalam setelah dilakukan pengaturan waktu. Selain itu dengan sistem ini TV dalam kondisi power off bisa menjadi power on melalui perintah suara dan tombol pada smartphone Android pemilik rumah. Pengendalian jarak jauh dapat dilakukan dengan internet yaitu mengakses URL website sistem yang dibangun. Bagi TV yang tidak terdapat tombol power on/off pada perangkatnya maka pemutusan arus listrik dikendalikan lewat stop kontak yang terintegrasi dengan sistem yang dibangun dengan media kendali yang sama yaitu internet dan Android. Dengan sistem yang dibangun, TV akan terpakai dengan lebih efektif dan menghindari terjadinya pemborosan energi listrik saat TV tidak ditonton.

\section{Metode Penelitian}

Metode yang digunakan dalam penelitian ini ialah metode Waterfall. Metode ini diadopsi karena memiliki tahapan yang urut, mulai dari analisa hingga testing and implementation. Setiap proses memiliki spesifikasinya sendiri, sehingga sistem dapat dikembangkan tepat sasaran pada tahapannya. Selain itu juga tidak terjadinya tumpang tindih selama proses pembangunan sistem.

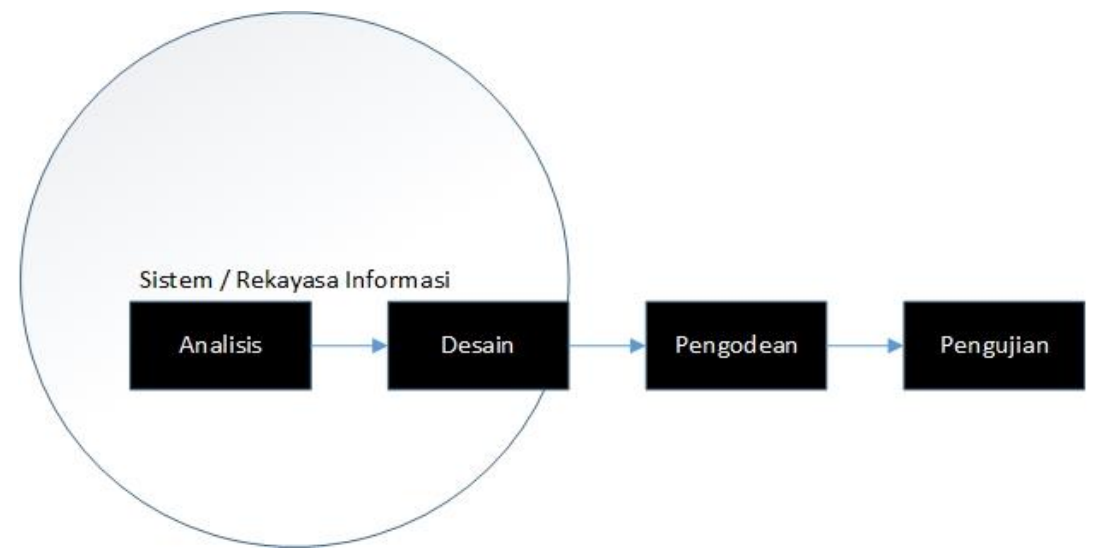

Gambar 2. Metode Waterfall.

Tahapan penelitian yang dilakukan berdasarkan metode Waterfall:

\subsection{Analisis Kebutuhan}

Tahapan ini dilakukan analisa terhadap kebutuhan calon pengguna sistem. Dilakukan sampling sederhana kepada beberapa responden untuk mendapatkan feedback terhadap sistem yang akan dikembangkan. Setelah mendapatkan feedback dari responden, analisis kebutuhan terhadap software dan hardware juga didefinisikan. Software yang digunakan untuk mengembangkan sistem ini di antaranya: Sublime Text, XAMPP, Arduino IDE, Google Chrome, Fritzing. Hardware yang diperlukan: Atmega328p Arduino Uno R3 DIP, Sensor IR, Selenoid 12V ZYE1-0503 electromagnet, Kabel Jumper dupont 20cm Male - Female, SYB170 Mini Breadboard Solderless PCB, Box Hitam X5 Kotak Plastik Casing Komponen X-5, Bluetooth module HC05 HC-05 serial pass-through for Arduino, NodeMcu ESP8266 esp12e WIFI development board CH340, Relay 2 Channel 5V Module, dan Power Supply Adaptor Switching Trafo LED Strip 12V 3A.

\subsection{Desain}

Desain dilakukan agar tahapan berikutnya dapat dilakukan terukur dan terarah. Desain atau modelling yang dibuat dalam pengembangan sistem ini ialah berupa Arsitektur Sistem dan Flowchart. Arsitektur menggambarkan rancangan dari penggunaan terhadap hardware yang dibutuhkan. Flowchart menggambarkan aliran penggunaan sistem yang dibangun mulai perintah diberikan hingga hasil akhir dari perintah tersebut. 


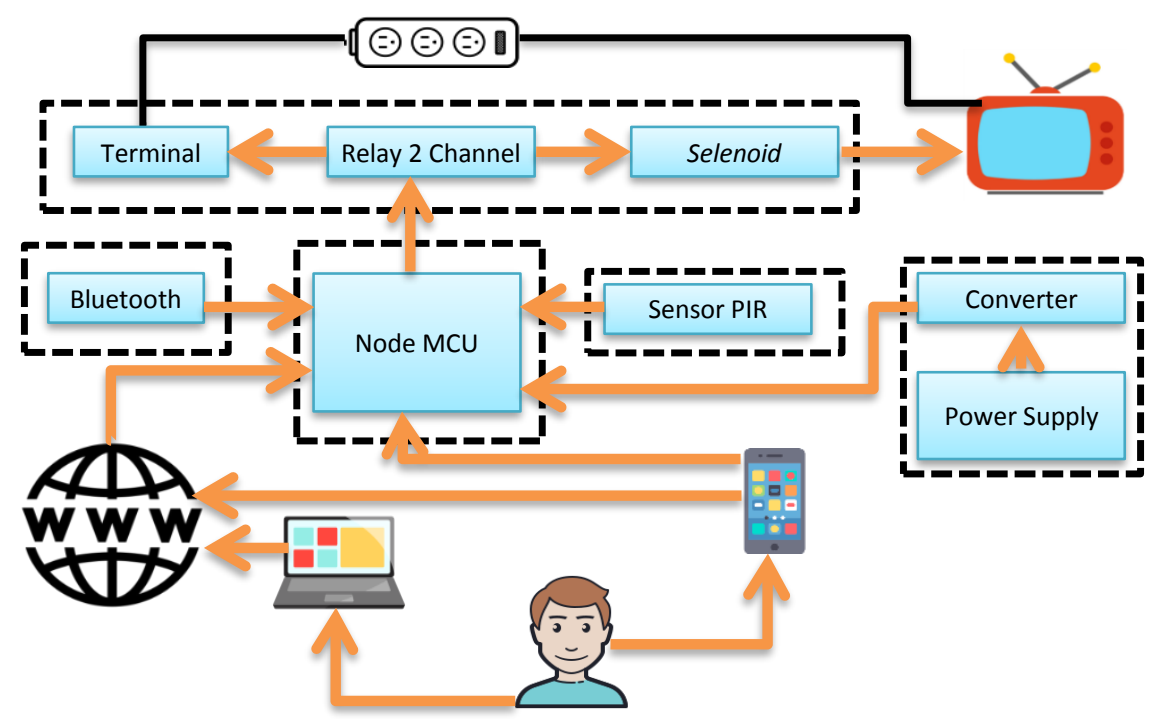

Gambar 3. Desain Arsitektur Sistem.

Desain Arsitektur Sistem menunjukkan rancangan hardware terhadap sistem yang dibangun. Modul Bluetooth, sensor PIR, dan converter daya terhubung dengan Node MCU. Node MCU merupakan sentral penerima perintah yang diberikan lewat Smartphone Android atau internet. Perintah yang diterima diteruskan ke relay untuk memberikan arus terhadap Selenoid atau Terminal listrik yang terhubung dengan relay.

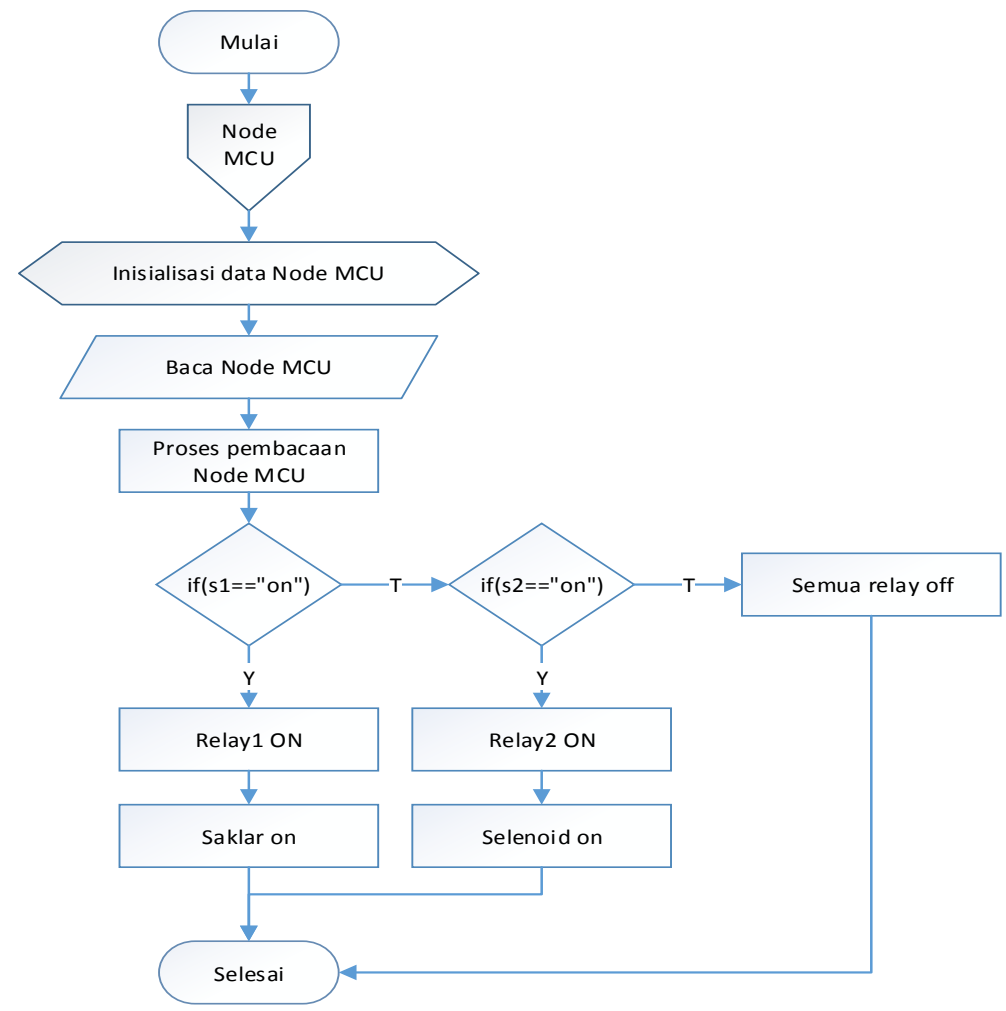

Gambar 4. Desain flowchart kontrol hardware.

Gambar 4 menunjukkan alur penggunaan sistem yang dibangun. Perintah yang diberikan oleh pengguna pertama kali akan diterima oleh Node MCU untuk dilakukan pemrosesan. Perintah yang diterima akan diseleksi, jika perintah ditujukan untuk relay pada Selenoid maka sakelar akan dilewatkan dan Selenoid akan bekerja dengan menekan tombol on/off TV. Sedangkan jika ditujukan untuk relay pada terminal/stop kontak maka terminal/stop kontak akan mengalirkan atau memutus aliran listrik. 


\subsection{Pengodean}

Pengodean dilakukan untuk mengembangkan aplikasi yang akan dipasang pada Android dan dihosting ke website. Pengodean untuk aplikasi Android menggunakan MIT APP Inventor. Pengodean untuk website menggunakan bahasa pemrograman PHP, HTML, dan MySQL sebagai basis datanya.

\subsection{Pengujian}

Tahapan akhir dari rangkaian metode Waterfall ialah pengujian, pada tahapan ini dilakukan pengujian secara menyeluruh terhadap aplikasi dan hardware yang dibangun. Pengujian dilakukan dengan Black Box berstandar ISO 9126-2 untuk fungsionalitas program. Pengujian hardware dilakukan dengan melakukan test case dalam beberapa kali untuk mengetahui error dan bug eksekusi yang diberikan lewat aplikasi. Pengujian responden juga dilakukan untuk mendapatkan tanggapan kemudahan penggunaan aplikasi untuk perbaikan.

\section{Hasil dan Pembahasan}

3.1. Hasil

Tahun 2018 Donny dan Masyhadi melakukan penelitian dengan membuat rancang bangun keamanan pintu rumah menggunakan Selenoid. Sistem yang dibangun dapat mengunci pintu melalui perintah pesan singkat (SMS) [10]. Umumnya Selenoid digunakan untuk dapat mengunci dan membuka pintu, dalam penelitian ini Selenoid digunakan dalam hal yang berbeda yaitu dimanfaatkan untuk dapat mendorong tombol Power on/off pada TV. Sistem dibangun terdiri dari software dan hardware. Software berfungsi untuk media komunikasi pengguna dengan hardware sedangkan hardware berfungsi untuk berinteraksi dengan tombol power on/off dan pemutus jaringan listrik TV.

\subsubsection{Rancangan Skematis Hardware}

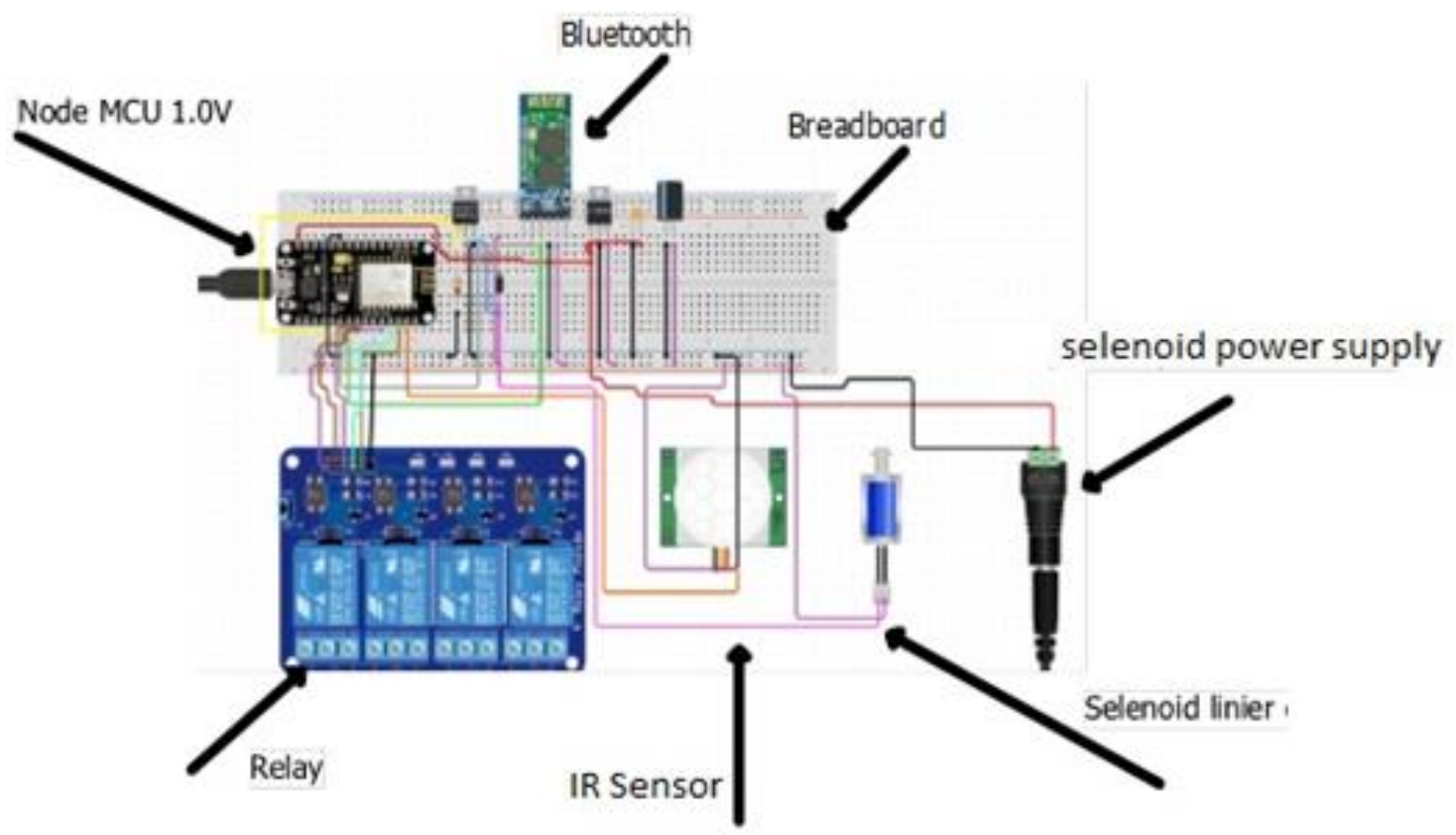

Gambar 5. Rancangan skematis hardware.

Penggunaan hardware pada sistem yang dibangun:

a. Node MCU 1.0V, dapat dianalogikan sebagai board Arduino ESP8266 yang berfungsi sebagai mikrokontroler dengan tegangan 3.3V yang sudah memiliki Wi-Fi atau ESP8266 di dalamnya, bertindak sebagai otak sistem yang telah dirancang;

b. Breadboard, sebuah papan kontrol untuk mengatur rangkaian skematis dari Node MCU, PIR, Selenoid dan relay;

c. Solenoid linier dorong, akan berfungsi jika ada daya yang dialirkan, dalam hal ini akan diatur oleh validasi dari sensor Bluetooth, Node MCU, dan relay sebagai pengatur aliran listriknya; 
d. Modul Bluetooth, sebagai validasi data yang dikirimkan oleh aplikasi Android yang sudah terinstal di smartphone untuk mengendalikan relay;

e. Relay, sebagai pemutus dan penyalur aliran listrik Solenoid dan sakelar listrik atau terminal;

f. Penyalur daya untuk Solenoid, sebagai penyalur daya tegangan listrik untuk menggerakkan Solenoid.

\subsubsection{Tampilan Hardware}
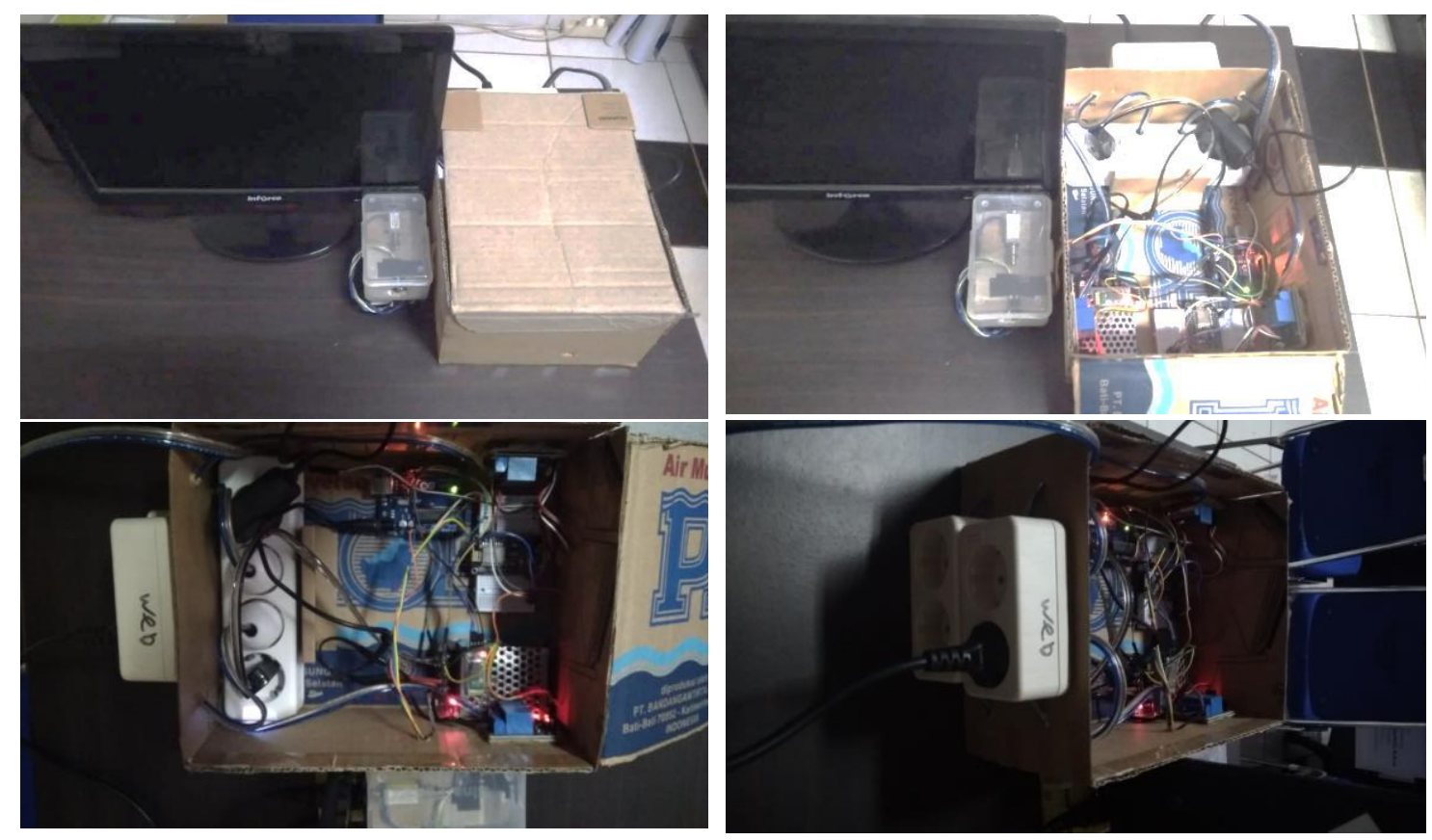

Gambar 6. Tampilan hardware.

Hardware yang dibangun terpisah dari komponen TV sehingga tidak dilakukan perubahan dan modifikasi terhadap TV. Hardware diletakkan di depan tombol TV agar dapat menjadi asisten pemilik TV untuk menjangkau tombol tersebut. Hardware bersifat portable sehingga bisa dilepas pasang untuk penyesuain jenis TV dan penempatannya. Total daya yang dikonsumsi oleh sistem yang dibangun ialah sebesar 30 Watt per jam.

\subsubsection{Tampilan Website}

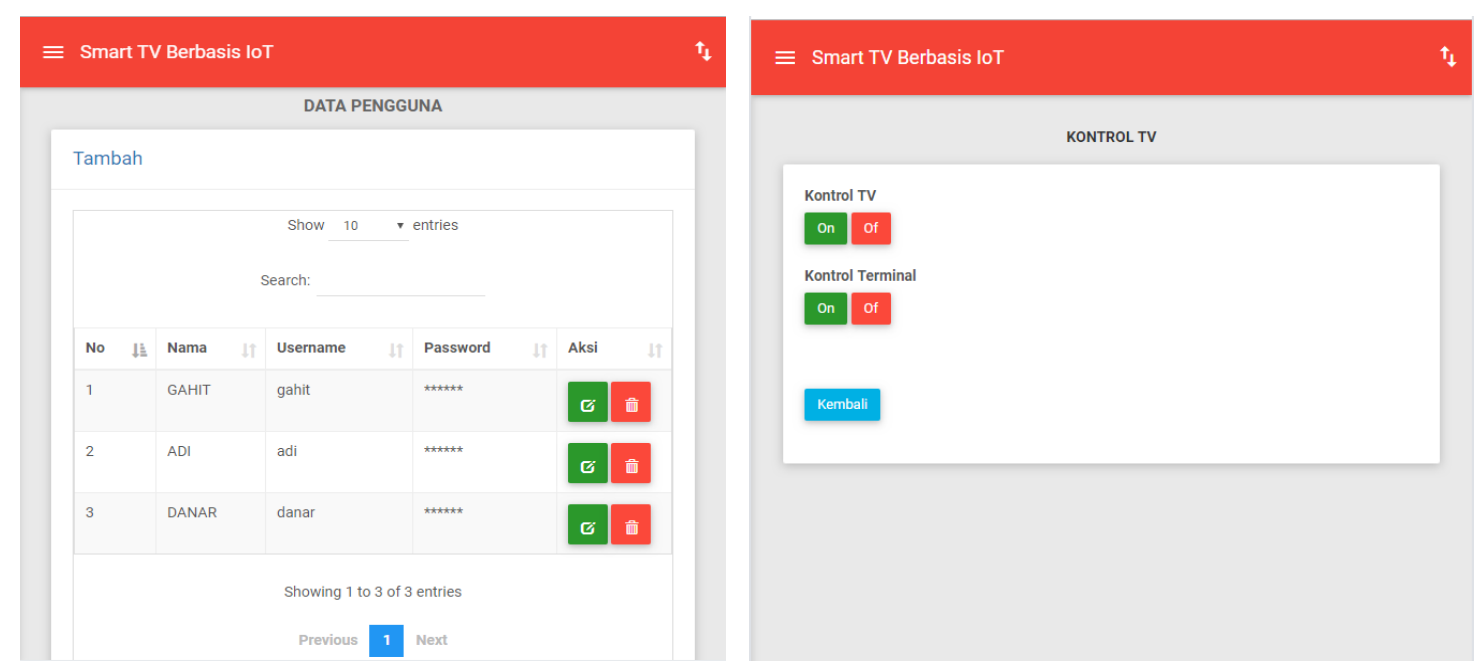

Gambar 7. Tampilan website.

Pengembangan Asisten TV Berbasis Internet of Things (IoT) untuk Efisiensi Penggunaan Energi Listrik (Herpendi) 
Pengendalian melalui internet dapat dilakukan dengan melakukan registrasi dan pemberian hak akses terhadap pengguna baru. Pemegang akses penuh pada website ialah admin. Pengendalian dapat dilakukan dengan fitur Kontrol TV dan Kontrol Terminal. Untuk Kontrol TV ialah pengendalian dengan memerintahkan hardware menekan tombol power TV, sedangkan Kontrol Terminal ialah pengendalian dengan memutus aliran listrik pada kabel power TV bagi TV yang tidak terdapat tombol power pada perangkatnya.

\subsubsection{Tampilan Aplikasi Android}

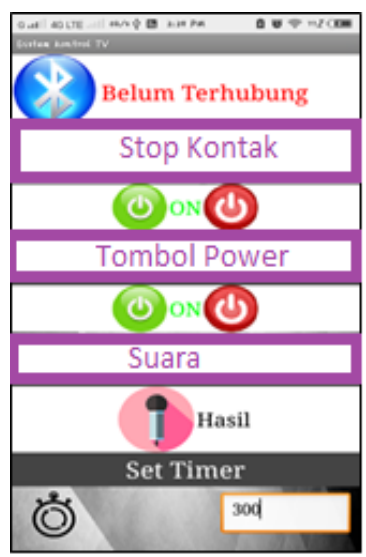

Gambar 8. Tampilan aplikasi Android.

Pengendalian melalui smartphone Android dapat dilakukan dengan 3 cara yaitu dengan menekan tombol on/off, dengan perintah suara dan pengaturan waktu. Ketiga cara tersebut menggunakan media Bluetooth untuk berkomunikasi dengan hardware. Tombol on/off sendiri memiliki 2 (dua) jenis kendali yaitu dengan memerintahkan hardware menekan tombol power TV, sedangkan Kontrol Terminal ialah pengendalian dengan memutus aliran listrik pada kabel power TV bagi TV yang tidak terdapat tombol power pada perangkatnya.

\subsection{Pengujian}

\subsubsection{Fungsionalitas}

Pengujian fungsionalitas dilakukan pada aplikasi yang terinstal pada smartphone Android. Pengujian mengacu pada metode Black-box ISO 9126-2 dengan faktor kualitas functionality dengan sub faktornya kualitas suitability. Terdapat tiga matriks dalam sub faktor ini yaitu Functional Adequacy, Functional Implementation Coverage, dan Functional Implementation Completeness. Dilakukan 6 test case terhadap fitur yang terdapat pada smartphone Android dan 4 test case pada fitur website. Rentang nilai pada standar ISO 9126-2 yaitu 0-1 dengan nilai 0 dinyatakan tidak baik dan nilai mendekati atau sama dengan 1 dinyatakan baik $(0<=X<=1)$.

Tabel 1. Hasil Pengujian Fungsionalitas

\begin{tabular}{llccc}
\hline Fitur & Media & FA & FIC & FICM \\
\hline Login & Internet & 1 & 1 & 1 \\
\hline Kelola User & Internet & 1 & 1 & 1 \\
\hline Kontrol Power On & Internet & 1 & 1 & 1 \\
\hline Kontrol Power Off & Internet & 1 & 1 & 1 \\
\hline Kontrol Stop Kontak On & Internet & 1 & 1 & 1 \\
\hline Kontrol Stop Kontak Off & Internet & 1 & 1 & 1 \\
\hline Button Stop Kontak On & Android & 1 & 1 & 1 \\
\hline Button Stop Kontak Off & Android & 1 & 1 & 1 \\
\hline Button Power On & Android & 1 & 1 & 1 \\
\hline Button Power Off & Android & 1 & 1 & 1 \\
\hline Kontrol Suara & Android & 1 & 1 & 1 \\
\hline Set Timer & Android & 1 & 1 & 1 \\
\hline & & &
\end{tabular}




\subsubsection{Respons Waktu}

Pengujian dilakukan dengan membandingkan 2 media yang digunakan yaitu akses melalui internet dan aplikasi yang terinstal pada smartphone Android. Masing-masing jarak dilakukan pengujian sebanyak 3 kali.

Tabel 2. Hasil pengujian respons waktu.

\begin{tabular}{lcc}
\hline Jarak (m) & Android (s) & Internet (s) \\
\hline $1-2$ & $<1$ & $1-3$ \\
\hline $3-4$ & $<1$ & $1-3$ \\
\hline $5-6$ & $<1$ & $1-3$ \\
\hline $7-8$ & $<1$ & $2-3$ \\
\hline $9-10$ & $<1$ & $2-3$ \\
\hline$>10$ & Tidak terhubung & $2-3$
\end{tabular}

\subsubsection{Konsumsi Listrik}

Perhitungan konsumsi listrik dilakukan untuk mengetahui sejauh mana sistem yang dibangun dapat berperan meminimalisasi terjadinya pemborosan penggunaan listrik lewat TV. Perhitungannya adalah sebagai berikut:

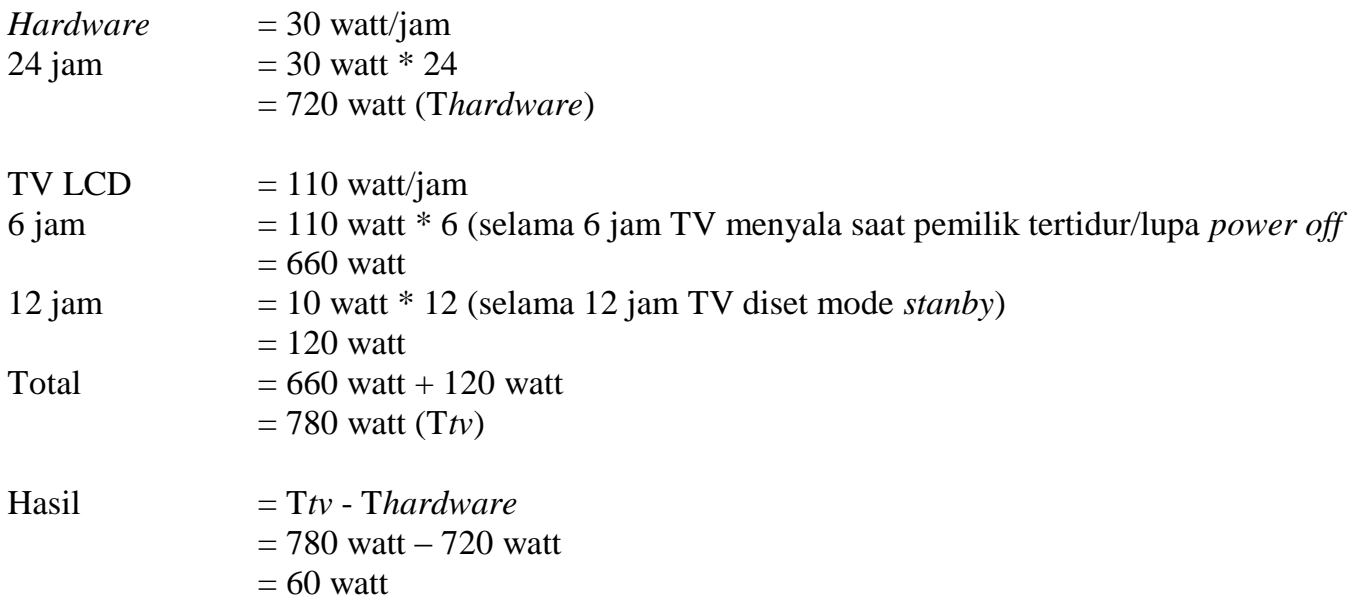

Perhitungan di atas mencakup penggunaan hardware yang dibangun selama 24 jam, TV menyala saat pemilik tertidur/lupa power off selama 6 jam dan penggunaan TV secara mode standby selama 12 jam. Dari hasil tersebut didapat angka penghematan listrik sebesar 60 watt/hari.

\subsubsection{Rangkuman wawancara responden}

Wawancara dilakukan untuk mendapatkan umpan balik terhadap sistem yang dibangun. Terdapat 3 keluarga responden yang memberikan umpan balik dalam penelitian ini. Pertanyaan yang diajukan terkait pengalaman pengguna ketika melakukan pengendalian melalui Android dan internet.

Tabel 3. Hasil Wawancara.

\begin{tabular}{|c|c|c|c|}
\hline \multirow{2}{*}{ No } & \multirow{2}{*}{ Pertanyaan } & \multicolumn{2}{|c|}{ Jawaban } \\
\hline & & Ya & Tidak \\
\hline 1 & Apakah aplikasi ini mudah dipelajari dan digunakan? & 3 & 0 \\
\hline 2 & Apakah sistem ini memiliki tampilan yang menarik? & 3 & 0 \\
\hline 3 & Apakah Anda kesulitan dalam menemukan seluruh fitur yang tersedia pada sistem? & 0 & 3 \\
\hline 4 & Adakah perbedaan yang Anda rasakan saat menggunakan sistem dengan tidak menggunakan sistem? & 0 & 3 \\
\hline 5 & Apakah ada bug/error yang terjadi saat menggunakan sistem ini? & 0 & 3 \\
\hline 6 & Apakah sistem ini memberikan dampak positif bagi Anda? & 3 & 0 \\
\hline 7 & Apakah sistem dapat memudahkan Anda dalam proses pengontrolan TV? & 3 & 0 \\
\hline 8 & Apakah terdapat fitur lain yang perlu ditambahkan pada sistem ini? & 1 & 2 \\
\hline 9 & Adakah kritik dan saran mengenai sistem pada penelitian ini? & 2 & 1 \\
\hline
\end{tabular}

\section{Kesimpulan}

Sistem yang dibangun terdiri dari software dan hardware. Dengan sistem yang dibangun TV dapat dikendalikan dengan tombol Power on/off atau dengan Terminal/Stop Kontak. Kedua pengendalian tersebut

Pengembangan Asisten TV Berbasis Internet of Things (IoT) untuk Efisiensi Penggunaan Energi Listrik (Herpendi) 
dapat dilakukan melalui smartphone Android dan internet. Pada smartphone Android perintah dapat dilakukan dengan tombol, suara, dan timer. Melalui internet (website) perintah dilakukan dengan tombol. Respon waktu menggunakan smartphone Android lebih cepat dibandingkan internet yaitu < 1 detik namun terbatas pada jarak maksimal $10 \mathrm{~m}$, berbeda dengan internet yang tidak terbatas jarak selama terkoneksi dengan jaringan. Namun pengendalian lewat internet tergantung dengan kualitas jaringan provider yang digunakan oleh pengguna. Respons dari responden terhadap sistem yang dibangun menunjukkan hasil yang positif. Terdapat saran dari responden yaitu jika sistem dapat melakukan kontrol power off secara otomatis pada TV yang sedang menyala saat pemilik tertidur atau meninggalkan TV maka akan lebih baik. Konsumsi listrik pada hardware yang dibangun sebesar 30 watt per jam, sedangkan pada TV LCD yang menyala ialah 110 watt per jam sehingga jika pemilik TV telah melakukan pengaturan waktu maka TV akan otomatis dikendalikan power off oleh hardware walaupun pemilik TV telah tertidur dan listrik pun tidak terbuang dikarenakan TV yang masih menyala. Dengan sistem yang dibangun penghematan listrik dapat diperoleh oleh pemilik televisi hingga $60 \mathrm{watt} /$ hari. Penelitian ini dapat menjadi pilot project penelitian lainnya terutama pengembangan ke arah penggabungan dengan komponen TV (embedded system).

\section{Ucapan Terima Kasih}

Penelitian ini dibiayai oleh DRPM DIKTI dengan kontrak nomor 043/SP2H/LT/DRPM/2019.

\section{Daftar Pustaka}

[1] T. T. Gultom, "Pemenuhan sumber tenaga listrik di indonesia," vol. 3, no. 1, 2017.

[2] H. A. Fitra and A. Asirin, "Ketahanan Masyarakat terhadap Ancaman Krisis Energi Listrik di Kabupaten Lampung Selatan, Provinsi Lampung," J. Wil. dan Lingkung., vol. 6, no. 1, p. 58, 2018.

[3] T. Suseno and H. Haryadi, "Analisis kebijakan pengendalian produksi batubara nasional dalam rangka menjamin kebutuhan energi nasional," pp. 23-34, 2013.

[4] F. Hanum, E. H. Nugrahani, Susanti, and S., "Pemanfaatan Sumber Daya Alam Terbarukan Dalam Model Sewa Ekonomi," J. Math. Its Appl., vol. 14, no. 2, p. 57, 2015.

[5] I. E. Agency, Things that go Blip in the Night. Paris: Sagim, 2001.

[6] G. Hamer, K. Delves, I. Saint-Laurent, N. Péloquin, M. Vladimer, and M. Scholand, "Canadian Standby Power Study of Consumer Electronics and Appliances," pp. 119-133, 2008.

[7] P. S. Solanki, V. S. Mallela, and C. Zhou, "An investigation of standby energy losses in residential sector: Solutions and policies,” Int. J. Energy Environ., vol. 4, no. 1, pp. 117-126, 2013.

[8] M. V. Shuma-Iwisi and George J. Gibbon, "Domestic appliances standby power losses: The case of eleven suburbs in the greater Johannesburg," in EEDAL'09 International Conference, 2009.

[9] M. Syahwil, Panduan Mudah Simulasi dan Praktek Mikrokontroller Arduino. Yogyakarta: Andi, 2013.

[10] Donny Widcaksono dan Masyhadi, "Rancang Bangun Secured Door Automatic System untuk Kemanan Rumah Menggunakan SMS Berbasis Arduino,” J. Kaji. Tek. Elekctro, vol. 3, 2018. 